settled down on the bolts, the sides retaining their form. There would have been little or no harm arising from this ; but the edges of the drum drew away from the sides, leaving sufficient space for a turn or two of wire, which became so firmly fixed in wheeling in, that it would part before clearing itself when sounding. This condition was caused, probably, by slack turns from time to time, when taking very deep soundings.

We were unable to examine the bar at the mouth of the Magdalena River because of the high winds.

The government of the republic and people of Barranquilla realize the necessity of providing a more practicable ontlet for their great river; and, with this end in view, surveys have been made for a deep-water terminus of the Bolivar railway.

We left Savanilla at 8.15 A.m. on the $22 \mathrm{~d}$, and ran a line of soundings west $\tilde{5} 2^{\prime}$, to the position in which the U.S.S. Powhatan reported shoal-water, where we found 1,175 fathoms, the water having deepened regularly since leaving port. From this point we ran a line south $40^{\prime}$, and being then $16^{\prime}$ west by north from Cartagena lighthouse, in 825 fathoms, we stood off'shore west-south-west $43^{\prime}$, then southsouth-east $51^{\prime}$, to a point $7^{\prime}$ north-west of Fuerte Island, where we found 38 fathoms. Soundings were taken at intervals of $10^{\prime}$ to $15^{\prime}$ since leaving Saranilla: the change in depth was gradual, making it extremely improbable that shoals exist ontside of the shore reefs. At 3.30 P.M. we started on a line west, sounding at intervals of $5^{\prime}$ to $20^{\prime}$, crossing the bay at the bottom of which lies the Gulf of Darien. At 4 p.M. we cast the trawl in 42 fathoms, green mud, latitưde $9^{\circ} 30^{\prime} 15^{\prime \prime}$ north, longitude $76^{\circ} 20^{\prime} 30^{\prime \prime}$ west, and at 4.55 another haul was made in 155 fathoms, green mud, latitude $9^{\circ} 30^{\prime} 45^{\prime \prime}$ north, longitude $76^{\circ} 25^{\prime} 30^{\prime \prime}$ west, both hauls furnishing us with a small number of good specimens.

The line was continued, sounding at various intervals, to Aspinwall, where we arrived at 2.5う P.M., March 25. The strict quarantine observed in this port, because of suspected yellow-fever, will, of course, prevent our' naturalists from making collections which I expected would be the most fruitful owing to the facility with which they could reach the interior by the railroad. The return home of Ensign A. A. Ackerman will restrict our investigations, as he has taken the branches of geology and mineralogy during the cruise.

We expect to sail to-morrow, April 2, running a line of soundings to Old Providence
Island, thence to Cape Sau Antonio, and to arrive in Key West about the 14th instant. [See Notes for account of the next cruise.]

\section{THE OLDER WIND-CHARTS OF THE NORTH ATLANTIC.}

THe series of charts of the North Atlantic now in preparation at our hydrographic office, of which three monthly sheets are just issued, recalls the famous work of Lieut. Maury, thirty years ago, with which our approach to a precise knowledge of ocean meteorology began. Current-charts go back to 1678 , when the first one for the Atlantic was published by Kircher, ${ }^{1}$ and the general circulation of winds was roughly shown as long ago as in the map by Dampier, ${ }^{2}$ of a little later date; but these, and all their successors down to comparatively recent years, were based only on general records, and not on the systematic apportionment of observations to definitely limited small areas of the ocean. 'The method of 'squaring' observations began with the English hydrographer, Rennell, about 1830, but was not then carried very far, and waited for its full expansion till taken up by the enthusiastic Maury. The remarkable series of charts published by him about 1850, for the Atlantic and Pacific Oceans, marks an epoch not only in our knowledge of the ocean, but in the progress of inductive meteorology; and the greater number of wind and current charts published since that time are taken very closely from his results.

The improvement in this kind of work during the past fifty year's has been not only towards greater accuracy, as permitted by the increase in the number of observations, but also in the method of charting, in which the aim has been to reproduce in a compact form, as clearly and fully as possible, all the original records, so that the navigator may recognize not only the average of the conditions of air and sea that he is to encounter, but the separate elements from which the averages are derived. Maury evidently perceived the importance of thus exhibiting observations as nearly as possible in their separate forms, instead of in the inaccurate generalizations of his predecessors; and this led him to the construction of the most realistic charts of the ocean that have ever been published. Not only the winds and currents were plotted in their place of observation, but the track and name of the vessel from whose $\log$ they were taken were mapped also. A small part of one of the North Atlantic wind and current charts is here reproduced in fig. 1 , omitting certain details concerning the strength of the winds, as well as the colors by which the seasons were distinguished. The full; broken, and dotted lines indicate months within the seasons. Nothing could be better adapted to emphasizing the reality of the work in the mind of the average sea-captain; and the result of the ingenious device was soon apparent in the general interest ex-

1 Ath. Kircheri, Mundus subterraneus. Edit. tert. Am. stelod., 1678, i. 134.

2 Discourse on the trade-winds, in his Voyages. London 1705 . 
cited among seamen in the study of the physical geography of the sea. It was a time of awakening to an opportunity of observation that had been too

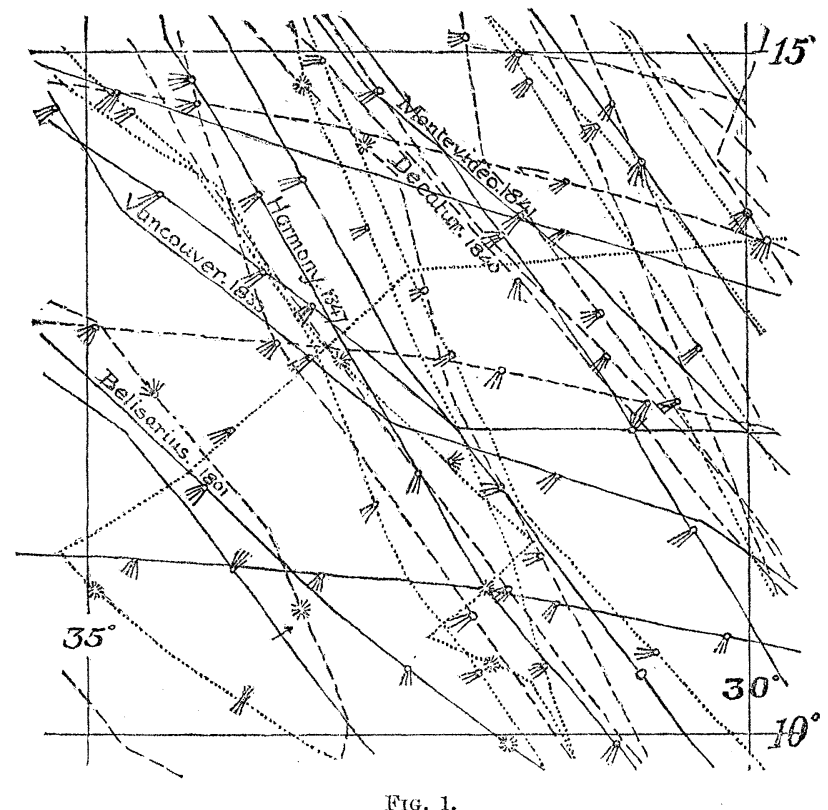

frequency of rain and storms. In the further devel. opment of the study, the treatment of the Atlantic winds will receive our chief attention.

About 185.5 a series of charts, based di rectly on Maury's Pilot charts, was prepared, under the direction of Admiral Fitzroy, for the London hoard of trade, on which the numerical form of record was replaced by graphic wind-roses for fivedegree squares. These are known as the Board of trade wind-charts. ${ }^{1}$ A little later Admiral Fitzroy published charts for the North Atlantic, showing winds, currents, temperatures, etc., for five-degree squares for February, May, August, and Novem. ber. These were based on logs obtained from the records of the Board of trade, as well as on Maury's charts. In 1868 the hydrographic office of the British admiralty published its 'Pilot charts for the Atlantic Ocean,' giving Maury's results, combined with those from all other attainable sources, presenting the whole in simple, graphic form, but without precise in dication of the original observations on which the averages were based. These are commonly quoted as giving the best general view yet published of the physical conditions of the Atlantic as a whole. Four large sheets show the winds for the four seasons, with the so-called 'limits of the

generally neglected before. But, in spite of their practical appearance, the Wind and current charts (or Track-charts, as they are commonly called) become unserviceable in the more frequented parts of the ocean, precisely where they are most needed, from the crowding together of observations. Along our coast and about the favorite longitudes for crossing the equator, the charts are unintelligible, except to the most painstaking examination, so completely are they covered over with a maze of signs and figures and a tangle of lines. This difficulty was overcome in the Pilot charts, on which the winds were singled out and counted for place and time; the style of record being shown in fig. 2 . The numbers in the corners give the total number of wind-observations for each month in the given five-degree square; December, January, and February being in the northeast corner, and the others following in the order of hours on a clock-dial. The sixteen sectors of the circle include the number of times the wind was recorded for every month from the several compasspoints to which they belong, the months being arranged as in the sector below the square. The centre contains the number of calms for every month in the same order as the total winds. The absence of graphic representation of the winds, and the confusion arising from the number of figures required to show the whole year's record on one sheet, were the chief disadvantages of these historic charts; but they were still vastly better than any thing of their time. Besides these, there were also prepared, about the same time, charts of the trade-winds and of the trades' for every month; but insufficient attention

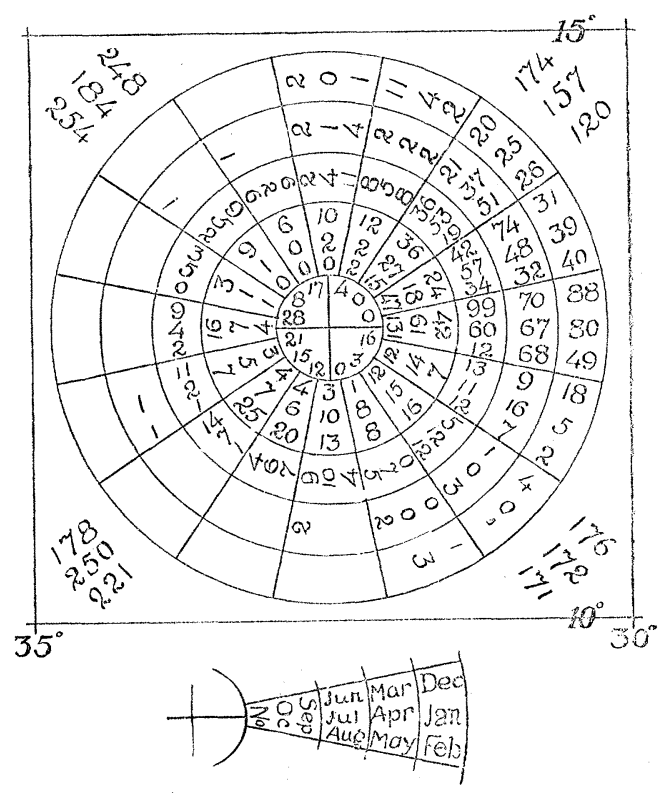

FIG. 2.

1 Publications of the meteorological department of the Lon. don board of trade. Wind-charts of the North Atlantic and other oceans. See the account of these charts by R. H. Scott, Quart journ. meteorol. soc., London, 1877, iji. 190. 
was given to barometric and thermometric conditions. A fifth chart gives the average direction of the currents for the year.

Four years later (1872), these were given more extended form in the "Wind and current charts for the Pacific, Atlantic, and Indian Oceans,' about on the same plan as before, but with the addition of isothermal and isobaric lines in small side charts, after the pattern of those prepared by Dove and Buchan. Part of the information in these charts was superseded, in 1872 , by a volume giving monthly maps of 'Currents and surface-temperatures of the North Atlantic Ocean, from the equator to latitude $40^{\circ}$ north,' prepared by R. Strachan, under the direction of R. H. Scott of the meteorological office. This is still the best work on North Atlantic currents and temperatures. The averages are here given for two-and-a-half-degree squares, from Maury's charts, Dutch observations, and some other. sources, with the number of observations on which they are based. It is very evident from this, that the currents, especially, need a much more extended examination than they have yet received, especially when one recalls the irregular variations lately determined by Commander Bartlett in so marked a current as the Gulf Stream. If the currents have regularly periodic changes, as seems probable at certain places, the precise determination of their form will require a sifting of observations down even into onedegree squares.

The publications of the Dutch meteorological institute at Utrecht have long been famous. In addition to their extensions of part of Maury's charts in $1856,{ }^{1}$ a more independent set of monthly charts for the several oceans was issued a little later, on which a simple graphic method of showing direction and frequency of winds was adopted. ${ }^{2}$

Until recent years, comparatively little original work on the North Atlantic was done in France. The British pilot charts of 1868 were republished, changed only by translation of the names and explanations from English into French. In 1863, Ch. Ploix published his 'Vents et courants, "outes générales,' compiled from Maury's and other works. A revised edition of this was issued in 1874. Since then, Lieut. L. Brault, in charge of the meteorological service of the dépist of charts and maps of the French marine, has undertaken extended studies of meteorology of the several oceans, based on twenty thousand selected logs ('toute une montagne de papier') of French vessels, dated between 1800 and 1870, and independent of the work of other nations. $\mathrm{He}$ states that the average accuracy of record is much

\footnotetext{
1 Maurij's wind-kaart voor het oostelijk gedeelte van den Noorder Atlantischen Oceaan, vermeerderd methollandsche gege vens.

Maurij's passaat.kaart van den Atlantischen Oceaan, vermeerderd met hollandsche gegevens.

$212 \mathrm{~W}^{\mathrm{T}}$ indkartjes van den Noorder Atlantischen Oceaan, etc. These were published in the Vitkomsten van wetenschap en ervaring aangaande winden en zeestroomingen in sommige gedeelten van den oceaan.
}

better than in the logs used by Maury. ${ }^{1}$ His first series of charts gives the probable direction and intensity of the winds for every three months in the North and South Atlantic, Indian, and Pacific Oceans, ${ }^{2}$ - sixteen sheets in all. In addition, a second series of monthly charts for the four oceans was to be prepared, showing winds, currents, rain, fog, cloudiness, squalls, storms, etc.; but these, I believe, are not yet completed. The accompanying cut (fig. 3) shows the graphic method of illustration used by Brault. The number in the middle is the number of observation for the square concerned. The radial bars show by their length the relative frequency of winds from the points of the compass to which they are directed. The different marking in these bars shows the relative frequency

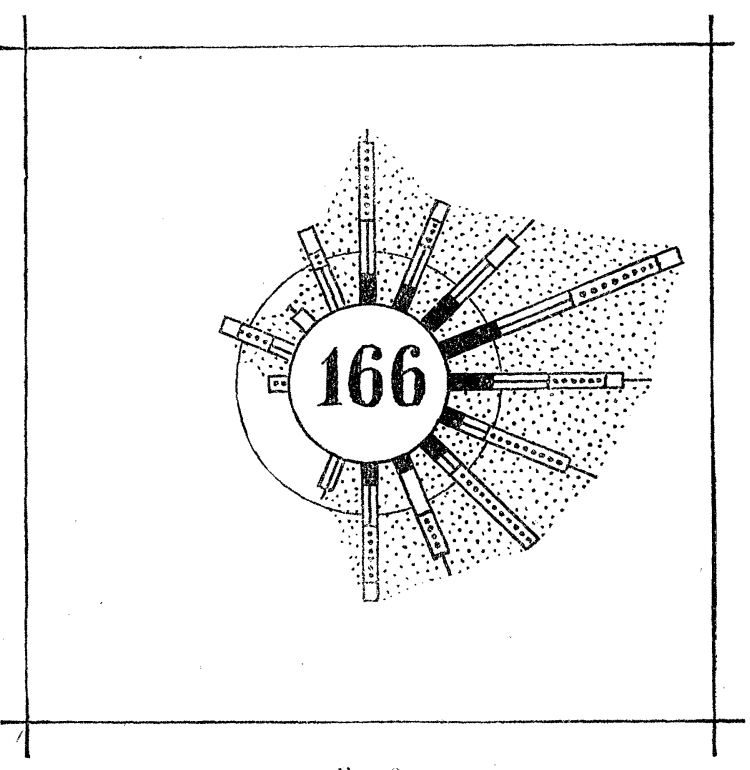

Hig. 3.

of five grades of strength, from heavy wind to light breeze. The ratio of the distance between the two concentric circles to the length of the longest arrow gives the percentage of calms. The detailed subdivision of winds according to their force is a special feature of this work. Brault notes that eighty observations in a five-degree square give trustworthy results for direction within the area of the trades; but three or four hundred are needed for the westerlies beyond the tropics. This statement is of value in enabling one to judge of the probable degree of precision in charts where the number of observations used in averaging is candidly given.

A valuable work, based_on Portuguese and Dutch

1 Etude sur la circulation atmosphérique dans l'Atlantique Nord pendant les saisons extrèmes. Paris, 1879.

2 Cartes de la direction et de l'intensite probable des vents dans l'Atlantique Nord, pendant les mois de -; 1874. Yd. dans l'Atlantique Sud; 1876. Id. dans la Mer des Indes; 1879. Id. dans l'Océan Pacifique; 1850 
observations, covering a comparatively small but very interesting part of the ocean, is found in the account of the Gulf of Guinea by Lieut. Brito-Capello of the Portuguese navy. ${ }^{1}$ The method of record here employed is easily understood, but does not give a measure of the number of observations used in averaging. Each fan is composed of arrows, showing the direc-

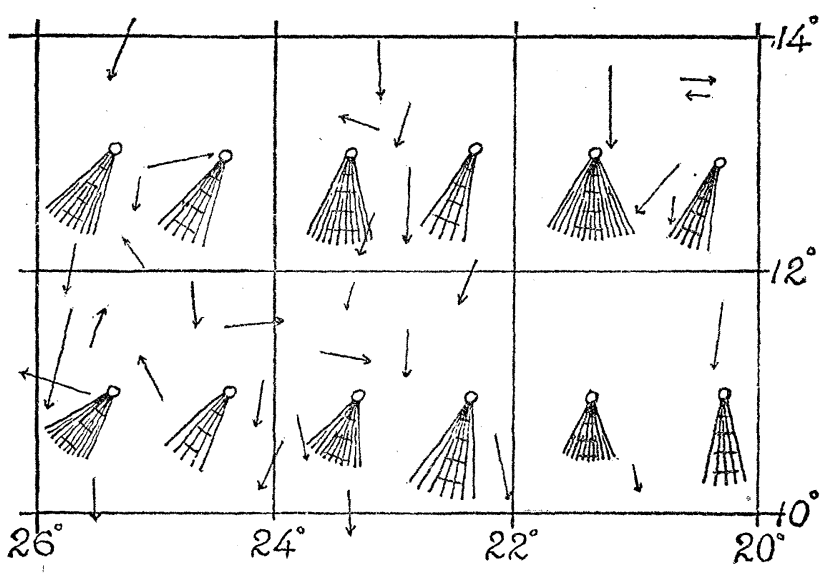

FIG. 4.

tion and velocity (estimated from distance made by sailing-vessels) of the local winds for a month. 'The angle of the fan measures the variability of the winds; and their length gives velocity, the, distance between the cross-bars corresponding to the rather indefinite sailing-rate of 'one knot an hour close to the wind.' 'The apex of the fan is toward the source of the wind. The current-arrows show average direction, when the original observations accorded; but near the coast, where observations do not agree closely, averaging was not attempted. The length of the arrow is on a scale of one millimetre to two miles and four-tenths a day. Fig. 4 is from the chart for March and April; the fine-ribbed fans being for one month, the coarse-ribbed for the other.

Three admirable monographs of a certain number of the ten-degree squares (ten degrees of longitude by ten degrees of latitude) into which the ocean is divided for the convenient partition of observations, have been prepared under the direction of Capt. Henry Toynbee of the British meteorological office, ${ }^{2}$ from logs of British vessels collected mostly between 1855 and 1870. The equatorial squares from north latitude $20^{\circ}$ to south latitude $10^{\circ}$, between Africa

1 Of this, I have only the French translation: Guide pous l'usage des cartes des vents et des courants du Golfe de Guinée par M. de Brito Capello. Paris, 1862.

2 Monthly charts of meteorological data for square 3; with remarks. London, 1874.

Montbly charts of meteorological data for the nine ten-degree squares of the Atlantic, which lie between $20^{\circ}$ north and $10^{\circ}$ south latitude, and extend from $10^{\circ}$ to $40^{\circ}$ west longitude; with remarks. London, 1876.' (The results for square 3 are repeated in this second volume.)

Meteorological charts for the ocean district adjacent to the Cape of Good Hope; with a volume on the gales of that region. London, 1880. and South America, were first studied, as the dol. drums of this region often cause vexatious delays to vessels crossing the line; and it is a problem of much importance to determine where the passage should be made. The group of squares about the Cape of Good Hope was next chosen as of difficult navigation, from their numerous gales and conflict. ing currents. These monographs are of the greatest value, not only to the seaman, but to the student as well; for they contain a large amount of information most carefully sorted out in time and place. Winds and isobars, temperature of air and water, currents, weather, clouds, etc., all have special record for ten subdivisions of every tendegree square, and for every month. They are shown, first, in diagrams that summa. rize all available observations ; and, second, most of these elements are given in charts of average monthly results. It is greatly to be hoped, both for practical and theoretical ends, that this excellent series of publications may be continued. Fig. 5 illustrates the concise method of detailed record of cer tain data for each of the ten subdivisions of the equatorial ten-degree squares. In the original, every thing relating to currents is printed in red. The number of observa. tions and mean force (Beaufort scale) of winds are given numerically, for every point of the com pass from which they blow, on the two inner circles and are further marked by arrows, whose length shows relative frequency, crossed by a curved line

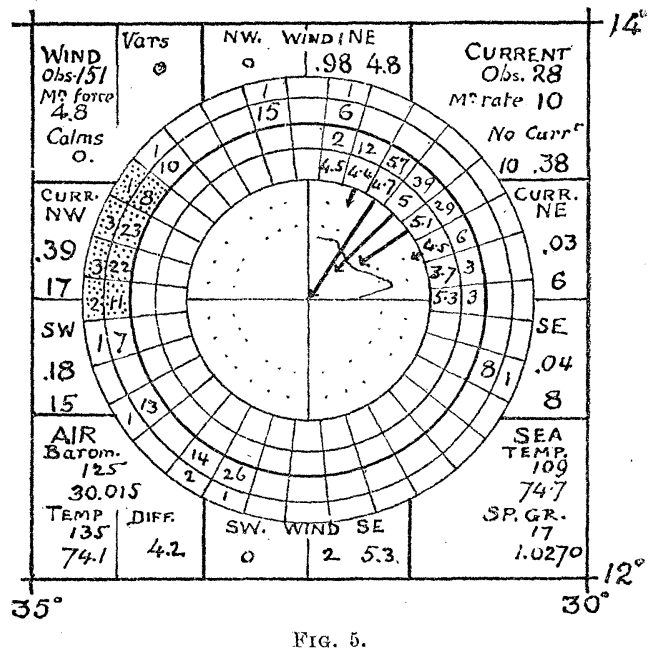

whose distance from the circumference shows force. Currents are plotted for the points of the compass toward which they flow in the two outer circles, the figures representing the number of observations and mean rate in miles per day. They are averaged for quadrants on either side of the circles; and an average of all currents is given in the upper right. hand corner of the square. Winds are similarly aver- 
aged at the top and bottom of the circles, and in the upper left-hand corner. The proportion of calms to winds is shown by the shading of a sector in the central circle (none noted in the square here copied). Number and average of barometer and air-thermometer observations are in the lower left-hand corner, with the average difference between dry and wet bulb thermometers. Temperature and specific gravity of the sea are similarly recorded on the right. The advantage of such record over final averages is at once apparent: it shows not only how well the various observations agree, but also the measure of trust to be placed in the results, as indicated by the number of observations. It is, of course, a little difficult to read at first, but, with a few days' practice, there is no further trouble. The charts for the Cape give less detail than those for the equatorial district, and their diagrams are of a much simpler pattern. Some of the more recent charts will be considered in a second article.

W. M. Davis.

\section{THE INDUSTRIAL ARTS AS FACTORS IN MODERN HISTORY. ${ }^{1}$}

A $\mathrm{T}$ the outset the lecturer suggested, as perhaps a more appropriate title for his remarks, 'Coal as a factor in modern history,' or 'Coal as the great reformer and revolutionizer.'

By reviewing past history, it would be noticed that certain great events had taken place, each of which marked a step in the advance of civilization. The connection between these events was not always apparent; but in fact they were interdependent, and formed a logical sequence, in many cases one directly or indirectly causing the next. The ancient Greeks were famed for their literary and aesthetic culture, in which they excelled all other peoples, ancient or modern. Their passionate temperament, however, and system of slavery, left unlaid the material foundations of permanent national prosperity. Again: the genius of the Romans had displayed itself in their military achievements; and, doubtless, Rome would have continued to be the mistress of the world, had it not been for the luxurious and profligate habits into which her people drifted, and through which she fell an easy prey to the barbarians. So monstrous were their excesses, that their punishment was inevitable and overwhelming. The excellence which those nations had attained had, no doubt, benefited succeeding generations.

The secret of true and permanent progress consisted in the application of science to the useful arts; and the development of this fundamental principle of progress had commenced only during more recent years. This was the power that had revolutionized social and political life. No one revolution had effected thorough and permanent changes. By the instrumentality of each, the light of liberty had shone for a brief interval, but the intolerance which was put down by it had been too often succeeded by equal

1 Abstract of a lecture delivered Saturday, April 19, in the U.S. national museum, Washington, D.C., by Prof. J. S. NEwBERRY of New York. Revised by the author. oppression on the part of those who had come into power. Yet each change had brought about a condition whereby the masses of the people had gained a greater or less advantage; and the power which each revolution had taken from the sovereign had been given to the people. These exchanges of power were more apparent in the history of England than of any country on the European continent. There the reign of every king had been despotic until the time of King Jolnn, when the Magna Charta was wrested from liim, and thus was taken the first step towards the true liberty of the subject. Henry VIII., disregarding all laws, human and divine, had assumed as much despotism of action as was compatible with the then slowly advancing state of civilization. Elizabeth, too, was conspicuous for her assumption of unlimited power. Nor was Cromwell's power less supreme than that of the kings and queens before him. Then followed the court of Charles II., with all its splendor and vice. But soon after, when the house of Hanover flourished, a certain popular power began to undermine the autocracy of royalty. Then the Earl of Chatham, the elder Pitt, albeit with much individual pride and haughtiness, and with no special sympathy with democracy, became champion of the English people, and wielded a power which had never before been held by any subject of the crown. Pitt declared that he represented the people of England, and Wilke's resistance to the royal party again and again caused his election as a member of the House of Commons. The last attempt at despotic power, on the part of the reigning monarch, was the unjust taxation by George III. of England's American colonies. Since that time the power of the subject had been increasing in England, and at this day there was no country in which the rights of the individual were more fully recognized. The conservatism of the English nation had not permitted the dethronement of rank and title. This was, in the opinion of the lecturer, probably the result of inheritance, not choice. He said, moreover, that the distinction of rank held in check the power of money, and refinement and culture were thereby advanced; but, if the present monarch were to attempt to resume the despotism of some of her predecessors, a storm of revolution would sweep away monarch and throne and peers. For this changed and ameliorated condition of affairs, special credit was due to Sir Robert Peel, Cobden, John Bright, and $\mathrm{Mr}$. Gladstone, the present premier. But the full triumph of democratic principles had not yet been fully realized in England, although it was rapidly approaching. It was worthy of note, that each Parliament introduced more liberal measures, and that the power of the House of Commons was fast superseding that of the House of Lords. England is now not only the home of freedom, but an asylum for the oppressed. Her shores are sought as places of refuge by fugitives of all kinds, who here found justice, and, if innocent, safety.

The moral and physical condition, too, of the present generation, is raised; and this age is conspicuous for its religious freedom, luxury, and the achieve- 